Bar

\title{
TRADICIONALNI I MODERNI PRISTUPI KNJIŽEVNOM TEKSTU U SAVREMENOJ NASTAVI
}

\section{Sažetak}

Klasična filologija predstavlja temelj svih budućih, tradicionalnih i modernih metodoloških pristupa u nauci o književnosti. Ako se osvrnemo na bazične postulate filoloških studija, nalazimo polazišta za svaku buduću analizu pisanog teksta: jezičku utvrđivanje lingvističkog koda na kome se tekst zasniva (a na čemu će u dvadesetom vijeku biti zasnovani unutrašnji pristupi tekstu - lingvostilistička i strukturalni metod), ali i za istraživanja konteksta u širem značenju te riječi - što je pretpostavka svih kasnijih, kako tradicionalnih tako i modernih spoljašnjih pristupa tekstu, počev od hvaljenog i osporavanog pozitivističkog metoda pa do popularne i prilično prihvaćene teorije recepcije. U radu ćemo istraživati koliko je svaki od savremenih metodoloških pristupa primjenjiv i pogodan u nastavi jezika i književnosti, koliko su današnji gimnazijalci upoznati sa osnovama savremenih metodoloških pristupa književnosti i pripremljeni da ih u izvjesnoj mjeri, primjereno uzrastu (tj. obrazovnom nivou i profilu) primijene u vođenoj i/ili samostalno rađenoj analizi književnog teksta. Posebno treba istaći mogućnost unapređivanja svijesti i sluha za svojevrsni pluralizam ideja i mišljenja koju implicira pluralizam metodoloških - i metodičkih - pristupa umjetničkom tekstu. U takvim vaspitno-obrazovnim sadržajima ujedno je ključ demokratskog vaspitanja i budućeg demokratskog kapaciteta jednog društva. Kreativni potencijal pojedinca i sposobnost divergentnog mišljenja prepoznaje se i razvija u procesu nastave književnosti i jezika, a različiti pristupi literaturi su ovdje takođe adekvatan programski sadržaj.

Ključne riječi: nastava književnosti i jezika, tradicionalni pristup, moderan pristup, unutrašnji pristup tekstu, spoljašnji pristup tekstu, kreativni potencijal, pluralizam 


\section{Uvod}

Umjetnički tekst je od davnina predmet naučnih analiza - bilo da su istraživanja usmjerena u pravcu preciznog datiranja rukopisa i dešifrovanja lingvističkog koda na kojem je tekst nastao (jezika, pisma i sl.), kao i mogućih intertekstualnih veza na koje djelo upućuje, ili pak da se posredstvom umjetničkog teksta pokušava saznati nešto više o istorijskom kontekstu, sociokulturnom miljeu i mentalitetskim matricama datog prostora i vremena, čime se nesumnjivo daje određen doprinos i drugim naukama (istoriji, arheologiji, sociologiji, antropologiji) ${ }^{1}$. Kako se filološkim istraživanjima, u svakom smislu, daje doprinos kulturi - to je i filologija kao nauka, uslovno rečeno, neodvojiva od kulturoloških studija: jezik je dio kulture, na određenom jezičkom kodu je zasnovana i izražena kultura, u jeziku su pohranjeni podaci koji o njoj najviše i govore. Međutim, ono što se ovdje želi naglasiti jeste činjenica da je od najstarijih vremena proučavanje teksta išlo u dva pravca: jedan je imao u fokusu sam tekst kao jezičku tvorevinu i sistem, drugi je uspostavljao veze sa kontekstom. Dakle, na neki način i klasična filologija utire put unutrašnjim (imanentnim) i spoljašnjim metodološkim pristupima umjetničkom tekstu.

$U$ radu se analizira mogućnost primjene različitih metodoloških pristupa književnom tekstu u nastavi jezika i književnosti. Pri tome imamo u vidu dvije klasifikacije:

1) onu po kojoj se pristupi umjetničkom tekstu dijele na

a) tradicionalne

b) moderne;

2) onu po kojoj se pomenuti metodološki pristupi svrstavaju u

a) unutrašnje

b) spoljašnje.

Pozitivistički metod predstavlja tipičan tradicionalni način bavljenja književnim tekstom. S obzirom na to da ga, između ostalog, karakteriše biografizam i istoricizam, ovaj tradicionalni spoljašnji metod se početkom

1 Govoreći o značaju pisma kao izuma u istoriji ljudske civilizacije, Bugarski (1996: 31) ističe: „U poređenju s tim, sve što je kasnije usledilo - uključujući i mikročipove današnjice može se svesti na niz tehničkih poboljšanja komunikacijskih kanala u čijoj osnovi ipak leži pismo." 
dvadesetog vijeka počinje smatrati prevaziđenim, a sama naučnost pristupa dovodi se u pitanje, upravo stoga što ovdje nije u fokusu sam umjetnički tekst kao zatvoren sistem, nego činjenice i događanja „oko teksta“.2

Najoštriji oponenti pozitivizmu u nauci o književnosti bili su strukturalisti i ruski formalisti, čiji je pristup tekstu upravo suprotan pozitivističkom, a što će reći - moderan i imanentan. Ruska formalana škola i strukturalizam umnogome se oslanjaju na lingvistiku. Tekst je jezička tvorevina i umjetnički znak i naučni pristup tekstu podrazumijeva analizu jezika i stila, umjetničkog postupka koji čini da jedan tekst zaista bude umjetnički (formalni metod). Tekst je slojevita struktura, a otkrivanjem tih slojeva predmetnosti, ideja, zvučanja i značenja, shematizovanih aspekata (Ingarden, 1931) - vrši se dubinska analiza teksta kao zatvorenog sistema. Jedino ovakvi pristupi mogu se smatrati naučnim jer se ne bave kontekstom, već samim sistemom umjetničkog teksta - smatraju pristalice imanentnih metodoloških postupaka u proučavanju književnosti, čiji stavovi dominiraju tokom XX vijeka.

Psihološki metod u proučavanju književnog djela uslovljen je razvojem psihologije i psihoanalize, a može biti unutrašnji i spoljašnji, u zavisnosti od toga da li se psihološka analiza primjenjuje u tumačenju samog djela (npr. psihološka uvjerljivost, motivisanost postupaka kod književnog lika) - ili pak u otkrivanju veze autor - djelo, pri čemu je u fokusu psihologija autora, kao i psihologija stvaranja uopšte. Arhetipsko, kolektivno nesvjesno i podsvjesno, takođe se očituje u umjetničkoj tvorevini (v. npr. Jung, 1996). Sociološki pristupi polaze od interakcije književnost - društvo, i takođe su intrigantni i plodotvorni tokom prošlog vijeka. Jedan od najmodernijih spoljašnjih pristupa tekstu jeste teorija recepcije, koja proučava relaciju autor - djelo - čitalac, a termin horizont očekivanja povezuje se sa vrijednosnim sudovima o samom djelu³. Jedan od interesantnih novih pravaca u metodologiji proučavanja literature jeste i fenomenološ-

2 Počeci pozitivizmma, upravo suprotno, vezani za napredak u nauci-posebno u egzaktnim i prirodnim naukama - i otuda, polazeći od „kulta činjenice“, i samo proučavanje književnosti vezuje se za spoljašnje aspekte teksta, za kontekst, jer se smatra da samo u tom dijelu može biti upotrebljiva „provjerljiva činjenica“ (npr. biografski podaci o piscu, istorijski kontekst rekonstruisan na osnovu fakata i sl.)

3 Smatra se da jedno književno djelo ima umjetničku vrijednost ukoliko pomjera, proširuje čitaočev vidokrug očekivanja, tj, sadrži neki, za čitaoca do tada još nepoznati kvalitet, pruža mu nov estetski doživljaj i sl. 
ki pristup koji stavlja u fokus dubinsku strukturu teksta i traganje za suštinom (otuda i izvjesna veza sa strukturalističkim konceptom, premda je fenomenološki metod prije svega filozofsko poniranje u "bit" umjetničkog teksta). Razvija se pod uticajem modernih filozofskih učenja i predstavlja jedan od imanentnih (unutrašnjih) pristupa književnosti.

Različiti metodološki pristupi književnom djelu već više od dvije decenije zastupljeni su u programima i udžbenicima u Crnoj Gori ${ }^{4}$, a pružaju velike mogućnosti za realizovanje različitih obrazovnih (i vaspitno-obrazovnih) ciljeva.

Na početku - još jedno kratko podsjećanje na to koliko je važno samo prisustvo književnog teksta u programskim sadržajima.

\section{Kreativni potencijali i nastava književnosti}

Danas, kada se zastupljenost književnog, umjetničkog teksta u nastavi jezika i književnosti polako ali sigurno smanjuje kako bi se više prostora dalo neumjetničkom tekstu u cilju razvijanja „funkcionalne pismenosti“ (što samo po sebi nije sporno) - nije suvišno još jednom podsjetiti na to da je funkcija književnosti kao umjetnosti u samom pedagoškom procesu nemjerljiva i nezamjenljiva.

Prije svega - treba naglasiti ulogu i značaj same nastave književnosti u vezi sa bitnim pitanjima koja se tiču formiranja ličnosti. $U$ tom smislu, istaći ćemo sljedeće:

a) problem darovitosti i kreativnih potencijala učenika

b) duh tolerancije i demokratičnosti.

Pedagogija kao nauka odavno se bavi problemom darovitosti i nastoji da pruži što potpuniji odgovor na pitanje kako je usmjeriti, kanalisati, oplemeniti, na dobrobit individue koja, prirodno, teži samoostvarenju, ali i društva, kolektiva kojem pojedinac pripada.

$4 \quad$ Aktuelni Predmetni program iz 2011. godine (v. str. 87), predviđa pojmove-sadržaje („metodologija proučavanja književnosti“, „unutrašnji i spoljašnji pristupi djelu“) i odgovarajuće aktivnosti („Učenik/učenica tumači književni tekst primjenjujući više metoda“), a sve je saobrazno nizu „operativnih ciljeva“ koji se suštinski svode na razumijevanje samih pojmova, uočavanje prednosti i nedostataka različitih pristupa i osposobljavanje za primjenu odgovarajućih pristupa $u$ istraživanju i tumačenju teksta. Programom je predviđena korelacija sa predmetima Istorija, Filozofija, Sociologija (ibid.), premda se tu u praksi otvaraju i brojne druge mogućnosti. 
Zvanično, učenici natprosječnih sposobnosti postaju predmet naučnog interesovanja, a sama tematika „etablirana“ u naučnoj zajednici na Prvoj svjetskoj konferenciji posvećenoj isključivo ovom pitanju, održanoj u Londonu 1975. godine.

“Moglo bi se reći da su već na Prvoj svetskoj konferenciji o darovitoj deci, koja je 1975. godine održana u Velikoj Britaniji, pokrenuta sva značajna pitanja i problemi (...) Skup u Londonu započet je pitanjem da li su darovita deca problem i kakve emocionalne poremećaje imaju." (v. Đorđević, Maksić, 2005: 126)

Uz konstataciju da darovita djeca uz visoke intelektualne sposobnosti po pravilu ispoljavaju i kreativnost - a što su istraživanja i potvrdila, na višim nivoima obrazovanja preporučuje se individualizacija vaspitanja $i$ ističe naglašenija potreba „za interdisciplinarnim i integrativnim pristupom u nastavi koji bi obezbeđivao temeljno opšte obrazovanje“ jer: „Da bi mogli da stvaraju, učenici moraju da imaju znanja; potrebno je stvarati klimu za stvaralački rad“ (127) (ibid., 127)

Uz podsećanje na konferenciju posvećenu takođe pitanjima darovitosti, održanu u Bangkoku 2002. godine („sa temom „Sjajni dečiji potencijali i kreativnost“) u ovdje citiranom članku ističe se pitanje „kako se mogu uvažiti emocionalne karakteristike učenika kada se poklanja mnogo više pažnje negovanju njihovih intelektualnih kapaciteta", pa se, između ostalog, izdvajaju sugestije „da kod učenika treba negovati i vaspitavati psihološke osobine i vrline (...) i učiti ih da cene književnost, kulturu i umetnost". (130)

I u osvrtu na Petnaestu konferenciju, održanu u Australiji 2003. godine, na kojoj se najviše pažnje posvetilo kvalitetu školskih kurikuluma, ali i pojmu interkulturalnosti i kreativnosti, podvlači se (ponovo) emocionalna osjetljivost i kompleksnost razvoja djece natprosječnih sposobnosti. Darovitost je problematizovana u pedagoškom kontekstu, sa posebnim osvrtom na osjetljiv, asinhroni razvoj - intelektualni, emocionalni, socijalni, fizički - karakterističan (ne uvijek, ali često) upravo za takvu djecu: („Asinhronost razvoja prate senzitivnost, prijemčivost, radoznalost, kompleksna i snažna ličnost, sklonost razmišljanju i perfekcionizmu, što vodi u preosetljivost i ranjivost." Ibid., 131). Uslijedila je i preporuka da se podsticanjem kreativnosti pomogne darovitoj djeci da se izraze i pronađu na- 
čine za ispoljavanje i ostvarivanje sopstvenih potencijela. Tu se predlažu i pokušaji pisanja poezije i razne druge kreativne aktivnosti.

Zadržaćemo se za trenutak kod ove pedagoške preporuke: učiti ih da cene književnost, kulturu i umetnost.

Na ovom mjestu ne možemo a da ne primijetimo kako upravo nastava jezika i književnosti otvara brojne mogućnosti za razvijanje „produktivnog mišljenja i kreativnosti“ (ibid.), bilo da je u pitanju stvaralački pristup umjetničkom tekstu (jedna od formi mogla bi biti pisanje eseja, na primjer, ili neki vid književnog stvaralaštva koji podrazumijeva međutekstovno nadovezivanje, intertekstualnost - bez obzira na žanr), stvaralaštvo u jeziku (koje se takođe može ispoljiti kao literarnost, ali i na brojne druge načine), ili pak inventivnost u čitanju, interpretaciji teksta, u smislu otkrivanja, ali i „dodavanja“, „dopisivanja“ značenja (aktivnog, kreativnog čitanja), što je legitiman postupak u kontekstu estetike recepcije (ili teorije recepcije) kao jednog od vodećih modernih spoljašnjih pristupa umjetničkom tekstu u metodologiji proučavanja književnosti.

$U$ ovom radu prvenstveno ukazujemo na raznovrsnost pristupa, pluralizam metoda u proučavanju umjetničkog teksta, što ujedno predstavlja vrlo prikladan programski sadržaj za (implicitno) podsticanje i njegovanje osobina kao što su otvorenost za drugačija mišljenja, spremnost da se stvari sagledavaju iz različitih uglova, prijemčivost za pluralizam ideja, stavova, pristupa - u najširem značenju te riječi. Dakle, riječ je upravo o svojstvima, sposobnostima i osobinama ličnosti kakve je potrebno njegovati u formativnom periodu kada se mlada ličnost priprema za život $u$ društvu sa demokratskim načelima i sistemom vrijednosti.

\section{1. Pluralizam mišljenja i nastava književnosti}

Kratko ćemo se osvrnuti na sve glasnije zahtjeve za uvođenjem u školski kurikulum adekvatnih sadržaja koji podstiču pluralizam gledišta, tolerantnost $i$ interesovanje za drugačije mišljenje o određenoj predmetnosti. Razumije se da potreba za ovakvim nastavnim programima korespondira sa socijalnom potrebom za demokratskim duhom i, uopšte, $k a-$ pacitetom za demokratiju, koji čine temelj građanskog društva (premda je svaka ozbiljna pedagogija, u svakom vremenu, ohrabrivala vaspitanike da „misle svojom glavom“, uče da argumentuju sopstvene stavove i budu otvoreni za one koji su drugačiji; u tom smislu, možemo primijetiti 
da „učenje demokratije“ u društvu koje pledira da bude demokratsko i/ili koje po svojim proklamovanim i sistemskim karakteristikama to već jeste - samo eksplicitnije postoji kao imperativ, iz čega proizilazi i princip da se ovakav pristup vaspitno-obrazovnom procesu sa više sistematičnosti i zvanično ugrađuje u programe ${ }^{5}$ ).

U ovom kontekstu valja primijetiti da je uvođenje posebnih predmeta kao što je Građansko obrazovanje ${ }^{6}$ samo jedan od načina da se u školi usvajaju znanja o demokratiji i vrijednostima građanskog društva, ali da pedagoška struka ukazuje na potrebu za određenim oblicima rada i sadržajima u okviru drugih nastavnih predmeta, koji su takođe pogodni za postizanje ovakvih vaspitvih ciljeva, a prednost im je u tome što implicitno, sa više spontanosti, prirodno upućuju na pluralizam kao osnovu stvarnosti u svim vidovima - a time i društvene stvarnosti.

Relacija pojedinac-društvo mora se imati u vidu u vaspitno-obrazovnom procesu, što rečeni zadatak čini složenijim:

„Demokratski pluralistički kontekst u svim svojim aspektima - intelektualnom, socijalnom, etičkom, razvija ideju o svetu alternativa i razlika kao resursu kvalitetnijeg zajedništva. Jedna od pretpostavki uspešne socijalne integracije osobe $u$ demokratsko društvo jeste sposobnost za stvaranje demokratskih odnosa. Budući da se obrazovanje i demokratsko vaspitanje odnosi na dve dimenzije, personalnu i društvenu, ova činjenica ima direktne implikacije na obrazovni sistem." (Đurišić-Bojanović, 2008: 54)

5 „Opšti cilj nastave književnosti i jezika jeste razvoj učenikove/ učeničine ličnosti, razvoj sposobnosti za društveni život i svrsishodno djelovanje, odnosno za aktivan život u demokratskom društvu koje se neprestano razvija." (Predmetni program Crnogorski jezik i književnost - I, II, III, IV razred opšte gimnazije, Ministarstvo prosvjete i sporta, Zavod za školstvo, Podgorica 2011, str. 97)

Napomena:

Program je nastao prilagođavanjem prethodnog, koji je pod nazivom Predmetni program Maternji jezik i književnost, I, II, III i IV razred opšte gimnazije - podgorički Zavod za školstvo odobrio nekoliko godina ranije, dok se i sam predmet u školama izučavao pod tim nazivom (i uz mogućnost dopisivanja jednog od četiri imena lingvistički istog jezika, po izboru). lako novi predmetni program nosi naziv Crnogorski jezik i književnost, sam predmet se u crnogorskim školama od 2011/12. izučava pod četvoroimenim nazivom: Crnogorskisrpski, bosanski, hrvatski jezik i književnost.

$6 \quad$ U crnogorskim školama Građansko obrazovanje se izučava kao izborni predmet za koji postoji posebno osmišljen nastavni program. 
Ukazujući na ključnu ulogu nastavnika čije kompetencije, bez obzira na sve prepreke i otežavajuće okolnosti, ostvarivanje ovakvih pedagoških ciljeva čine mogućim, autorka podsjeća na elemente vaspitnih i metodičkih postupaka koje prvenstveno ovdje treba imati u vidu:

„Učenje učenika uvažavanju činjenica, preispitivanju njihovog značaja u različitim vremenima iz različitih uglova, analiziranje i upoređivanje podataka iz različitih izvora koji se odnose na isti fenomen, iznošenje alternativnih gledišta i ideja, obrazlaganje argumenata koji ih podržavaju ili dovode u pitanje, predstavljao bi deo profesionalne kompetencije nastavnika u procesu obrazovanja za demokratiju." (ibid.)

Ovdje je, između ostalog, riječ o „demokratskom stilu podučavanja“ koji se ogleda $u$ „spremnosti za prihvatanje pluraliteta ideja, kao prihvatanja legitimnosti postojanja različitih objašnjenja mnogih pojava i spremnosti da se razmatra argumentacija za nesaglasna ili suprotna gledišta unutar kontroverznih tema." (ibid.)

Vratimo se tematskom fokusu ovog rada.

Priroda književnosti kao umjetnosti koja u sebi pored estetskog objedinjuje sve pomenute aspekte i dimenzije - „intelktualnu, socijalnu, etičku“ (a i mnogo više od pobrojanog) i koja je kao takva ponekad „subverzivna" - već po sebi poziva na neku vrstu otvorenog dijaloga, komunikacije sa tekstom. Iz te njene prirode proizilazi i potreba čitaoca/istraživača/ interpretatora/kritičara - da umjetnički tekst osvijetli iz najrazličitijih uglova, da istražuje književnu tvorevinu u kontekstu (spoljašnji pristupi) ili da analizira tekst kao zatvoren sistem (unutrašnji pristup), što je rezultiralo i pluralizmom metoda u nauci o književnosti i književnoj kritici. Dakle - imamo upravo u ovoj oblasti jedan bogati i bogomdani pluralizam, vrlo pogodan za spontano ostvarivanje pomenutih ciljeva u vaspitno-obrazovnom radu.

3. Metodologija proučavanja književnosti kao pluralizam pristupa umjetničkom tekstu jeste, dakle, jedno od najboljih programskih polazišta za ostvarivanje brojnih ovdje pomenutih ciljeva. Osvrnimo se na neke od mogućih metoda analize i tumačenja teksta koji pružaju neograničene mogućnosti za različite oblike rada i razumijevanje različitosti mišljenja, stavova i recepcije umjetnosti izražene u jeziku: 
a) pozitivistički metod (tradicionalni spoljašnji pristup književnom djelu);

b) fenomenološki metod (unutrašnji pristup);

c) psihološki

d) formalni

e) strukturalistički

f) estetika recepcije

Izdvojili smo dominantne pristupe književnoj umjetnosti koji su obilježili dvadeseti vijek i otvorili mogućnost za pluralizam pristupa i njihovo sadejstvo, što predstavlja nezamjenljiv savremeni („pluralistički“) metod kada je u pitanju analiza, interpretacija i vrednovanje umjetničkog teksta u nauci o književnosti i književnoj kritici.

Čuveni predstavnik ruske formalne škole (kojeg dovode u vezu i sa strukturalizmom), eminentni član praškog lingvističkog kruga, koji je nesumnjivo dao veliki doprinos i nauci o jeziku i nauci o književnosti, često je naglašava stav (lični, ali i škole kojoj je pripadao) o tome šta treba da bude predmet naučnog istraživanja književnog teksta:

„La poésie c'est le language dans sa fonction esthétique.

Ainsi, l'objet de la science de la littérature n'est pas la littérature mais la littérarité, c'est-à-dire ce qui fait d'une oeuvre donnée une oeuvre littéraire." (Jakobson, 1977: 16) ${ }^{7}$

lako je ovakav pristup literaturi u najvećoj mogućoj mjeri naučni - književnost je toliko raskošna i tako bogato kontekstualizovana da neizbježno poziva i na interdisciplinarna istraživanja, a time i na spoljašnje pristupe tekstu. ${ }^{8}$

U nastavku ćemo obratiti pažnju na to kakve mogućnosti otvaraju u nastavi književnosti i jezika.

3.1. Interdisciplinarnost, integrisana nastava i raznovrsnost metodoloških i metodičkih pristupa prepliću se i međusobno uslovljavaju.

$7 \quad$ „Poezija je jezik u estetskoj funkciji.

Prema tome, predmet nauke o književnosti nije literatura nego literarnost, što će reći ono što jedno djelo čini književnim djelom." (prev. Gordana Janjušević Leković)

8 Već semiotičko-strukturalna, tartuska škola kojoj pripada Jurij Lotman (v. npr. Lotman, 1976), premda se umnogome naslanja na ruske formaliste, istovremeno u značajnoj mjeri obogaćuje polje istraživanja teksta. Međutim, osnovne smjernice su iste: ono što je kod formalista oneobičavanje, začudnost, kao osnova estetike teksta, kod Lotmana je „narušavanje strukture“, ali ono koje aktivira estetsku informaciju (ibid., 381) 
Tako unutrašnji pristupi, tj analiza teksta u smislu otkrivanja umjetničkog postupka, literarnosti - podrazumijeva unutarpredmetnu korelaciju književnost - lingvistika u širem smislu te riječi, a to znači i mogućnost kako unutarpredmetne (književnost . jezik, u okviru nastave maternjeg jezika i književnosti), tako i međupredmetne korelacije između maternjeg i stranih jezika (izazov prevođenja književnog teksta), ali i maternjeg jezika i književnosti i muzike (ritam, pauza, akcenat, eufonija, melodičnost - naročito u poeziji).

Srednjoškolcima su ipak često interesantnja tumačenja koja uključuju mogućnost „dopisivanja značenja“, učitavanja sopstvenih ideja i vrijednosnih sudova o pročitanom - što je prostor teorije recepcije. Prijem književnog teksta i, uopšte, relacija autor-djelo-čitalac, podrazumijeva da je čitalac pozvan da bude aktivni učesnik, „ko-autor" i kreator, što je izazov za mladog čitaoca. Takođe, nije im strano ni „psihologiziranje“, a ponekad se zanimaju i za društveno-istorijski kontekst, pa i za biografiju pisca.

Sve navedeno treba imati u vidu kada učenike treba motivisati da čitaju i razmišljaju o pročitanom djelu. Ovo tim prije što moderna nauka o književnosti ne odbacuje nijedan metodološki pristup tekstu, pa ni onaj koji se u prošlom vijeku smatrao prevaziđenim - pozitivistički. Naprotiv, uzima se u obzir i literarnost kao takva, ali i sav kontekst u koji se uključuje jedan književni tekst - tako da se svaki metod smatra dobrim ukoliko je odgovarajući s obzirom na temu i ciljeve istraživanja. Upravo je pluralizam metoda potreban za cjelovitu, zaokruženu analizu teksta.

Pri tom, svakako ne treba zaboraviti da je znalačko vođenje učenika (mladih čitalaca) od izuzetnog značaja. Literatura bogati i oplemenjuje ličnost - što je u formativnom periodu posebno važno, ali, sa druge strane, traži i odgovarajući zrelost čitaoca: ako je nema, moguća je i neadekvatna recepcija teksta i njegovh značenja. Umjetnički tekst podstiče imaginaciju, razvija prostor fikcije, ističe vrijednosti i poziva na diskusiju, provocira "konflikt", i upravo zato, kako ističe Žan-Šarl Šaban u svom plenarnom predavanju na 7èmes Rencontres des chercheurs en Didactique de la Littérature - „ce travail complexe de la pensée et de l'émotion liées ne peut être laissé au seul heureux hasard“ ${ }^{\prime 9}$

$9 \quad$ "Taj kompleksni misaoni rad i vezane emocije ne treba prepustiti srećnoj slučajnosti“ (JeanCharles Chabanne . „Parler, lire, écrire dans la classe de littérature: l'activité de l'élève / le travail de l'enseignant / la place de l'oeuvre", Conférance d'ouverture, 7èmes Rencontres des chercheurs en Didactique de la Littérature, IUFM de Montpellier, 6 au 8 avril 2006) 
Sa druge strane, u eri „hipertrofirane " „kvazi-neograničene“ ponude $u$ „,kulturalnom supermarketu“, kako stanje u „hipermodernoj“ kulturi živopisno sagledavaju francuski sociolozi i filozofi Lipovecki i Seroj (v. Lipovetsky, Serroy, 2016: 440, 441) - dati mladom čitaocu dobro literarno djelo i učiniti ga otvorenim za taj, u samom ljudskom jeziku bogato estetizovani svijet - predstavlja pravo pregnuće i vrijednost po sebi.

4. Rezultati nedavnog preliminarnog istraživanja koje smo ovom prilikom obavili u Gimnaziji u Baru pokazuju raznovrsnost interesovanja učenika kada je riječ o načinu na koji će se pristupiti istraživanju (analizi/ interpretaciji) književnog djela - što je u saglasju sa stavom u savremenoj nauci o potrebi za jednim pluralizmom metoda, odnosno pristupa umjetničkom tekstu. Vidjećemo da nekim aspektima proučavanja književnog ostvarenja gimnazijalci ipak daju blagu prednost.

Kao (sa njihovog stanovišta) interesantniji aspekt $u$ analizi i tumačenju teksta gimnazijalci navode proučavanje konteksta (nastanka) književnog djela (50\%), a tek onda analizu/ interpretaciju samog umjetničkog teksta kao organizovanog umjetničkog oblika i zatvorenog sistema (33, $33 \%)$, dok je određen broj ispitanika bio u dilemi (16, $67 \%)$. Dakle, metod koji u nauci o književnosti terminološki slovi kao spoljašnji, prema podacima koji proizilaze iz pomenutog istraživanja - odnosi izvjesnu prevagu, ali ne izostaje ni zanimanje za unutrašnji pristup umjetničkom tekstu.

$U$ vezi sa mogućnostima samog spoljašnjeg pristupa, odnosno proučavanja konteksta djela ${ }^{10}$, naši ispitanici najviše se zanimaju za pitanja koja proizilaze iz oblasti psihologije stvaranja, $\mathrm{tj}$. najradije bi tragali za odgovorima na pitanje kako psihološke karakteristike ličnosti stvaraoca utiču na samo njegovo stvaralaštvo i uslovljavaju oblik i značenja umjetničkog djela (blizu $60 \%$ ispitanika). Kao primjer, neki ispitanici navode djela Dostojevskog, ali tu je i „Mali princ“ Sent-Egziperija, uz objašnjenje da je to „drukčije djelo od ostalih... pa sigurno ima neke naglašenije veze sa ličnošću stvaraoca i psihologijom stvaralaštva...", a što bi, po njihovom mišljenju, bilo zanimljivo istraživati.

$\mathrm{Na}$ drugom mjestu u vidokrugu njihovog interesovanja nalaze se društvene prilike i ekonomski odnosi u jednom vremenu i na određenom

10 Ispitanicima je ponuđeno pet najčešćih vidova istraživanja koji se mogu podvesti pod termin spoljašnji pristup, uz mogućnost da biraju do tri odgovora. Jedna trećina ispitanika birala je manje od tri ponuđena odgovora. 
prostoru kojima je pisac bio inspirisan (48,7\%). Kao djela pogodna za ovakva proučavanja konteksta gimnazijalci navode Balzakov roman „Čiča Gorio“ i Tolstojevu „Anu Karenjinu“.

Trećina ispitanika pokazuje interesovanje za proučavanje istorijskog perioda o kom govori književno djelo (navode kao primjer roman „Seobe“ Miloša Crnjanskog, romane i pripovijetke Ive Andrića, kao i djelo „Poslednji ruski car" R. Aleksandera, koje, za razlliku od većine pomenutih tekstova, nije zastupljeno u programu kao obavezna lektira), a nešto manji broj (25\%) zanimao bi se za istorijski period u kojem je živio sam autor i mogući uticaj istog način umjetničkog stvaranja (autentični pečat trenutka u kom djelo nastaje). Kao djela pogodna za ovakva istraživanja konteksta gimnazijalci navode, između ostalih, roman „Proces“ Franca Kafke i Selindžerovo djelo "Lovac u žitu“.

Najmanji broj ispitanika u okviru ovog preliminarnog istraživanja pokazuje interesovanje za biografiju autora (16, 7\%).

$U$ vezi sa mogućim istraživanjima u okvirima unutrašnjeg pristupa književnom djelu ${ }^{11}$, opet je prevagnuo psihološki metod, ali ovoga puta u vezi sa pitanjima građenja, odnosno analize književnog lika (dakle, sada kroz unutrašnji pristup, psihološku analizu koja ne izlazi iz okvira samog umjetničkog teksta). Psihološka analiza književnog lika interesantna je većini ispitanika, a pojavljuje se vrlo sličan procenat kao i kada je riječ o interesovanju za psihologiju stvaraoca u okviru spoljašnjeg pristupa tekstu (60\%). Gimnazijalci smatraju da bi „psihologiziranje“ unutar teksta dalo zanimljive rezultate kada je riječ o Kapotovom djelu „Doručak kod Tifanija" (pomalo čudan i tajanstven lik Holi Golajtli koji navodi na razmišljanje o uzrocima i psihološkoj motivaciji) ili pak „Smrt na Nilu“ Agate Kristi - jer uspio detektivski roman po pravilu mora biti skopčan sa tanano iznijansiranim psihološkim portretima likova. I kada je u pitanju psihološki metod kao unutrašnji pristup tekstu nezaobilazno je ime Dostojevskog. Na drugom mjestu je (vrlo povezano sa prethodnim) zanimanje za umjetnički postupak kojim se postiže uvjerljivost u građenju književnog lika $(41,7 \%)$, a zatim slijedi izbor trećine ispitanika (33,33\%) kojima je posebno interesantno istraživati umjetnički postupak (ukupnost jezičko-stilskih sredstava i način organizacije teksta uopše) kojim se postiže vrhunski estetski domet, proizvodi viši oblik ljepote i uzvišene duhovnosti (estetski

11 Od devet ponuđenih mogućnosti ispitanici su mogli da biraju do pet, ali je polovina ispitanika zaokružila manji broj odgovora. 
učinak teksta, umjetnička ljepota koja oplemenjuje). Ispitanici su, između ostalih, kao primjere naveli naslove vrhunskih pjesničkih ostvarenja kao što je Kostićevo djelo „Santa Maria della Salute“, Disova pjesma „Možda spava", Njegoševa "Noć skuplja vijeka".

Približan stepen interesovanja (27\% do $31 \%$ ) gimnazijalci su ovom prilikom ispoljili za gramatičku analizu teksta, proučavanje poetske funkcije pravopisa, umjetnički postupak (jezičko-stilska sredstva, ukupna organizacija teksta) u funkciji dočaravanja emocije i atmosfere, kao i za istraživanje leksike u umjetničkom tekstu. Određeni broj ispitanika $(16,6 \%)$ pokazuje interesovanje za analizu autentičnog jezika vremena $i$ prostora u kom je djelo nastalo (,šekspirovskog “ i Šekspirovog engleskog, Homerovog grčkog i sl.) $)^{12}$, ali treba naglasiti da su za ovakvu analizu teksta uglavnom zainteresovani učenici sa najboljim rezultatima u učenju maternjeg i stranih jezika. Za gramatičku analizu umjetničkog teksta učenici bi izabrali djela Bore Stankovića, poetska funkcija pravopisa intrigira ih kada je u pitanju Crnjanski. Kao tekstove primjerene za analizu postupka kojim se dočarava atmosfera navode sljedeće naslove: „Gavran“E. A. Poa, „Romansa mjesečarka“ Federika Garsije Lorke, „Jesenje veče “ $A$. G. Matoša...

lako anketirani gimnazijalci uglavnom nisu uspijevali da objasne književnoteorijski termin teorija recepcije - ispitivanje pokazuje da ipak imaju određene stavove o relaciji autor-djelo-čitalac, odnosno o prijemu umjetničkog teksta, što je i predmet ovog modernog spoljašnjeg metoda u nauci o književnosti.

Od šest ponuđenih stanovišta ispitanici su mogli da biraju bez ograničenja, sa izuzetkom međusobno protivrječnih tvrdnji.

Navodimo redom pomenuta stanovišta i procenat ispitanika koji ih smatraju prihvatljivim ili istinitim:

a) Djelo je zatvoren sistem i zasebna cjelina i njegova vrijednost ne zavisi od recepcije čitaoca $(16,66 \%)$

b) Djelo živi ne kao zatvoren sistem i zasebna cjelina, već samo na relaciji autor-djelo-čitalac (21\%)

12 Ispitanici su ovo uglavnom shvatili kao interesovanje za „stari jezik“, arhaične idiome i sl., što se može zaključiti iz njihovih kratkih komentara i na osnovu primjera koje navode. Inače, prošlogodišnje istraživanje, u okviru teme „Originalni umjetnički tekst, prijem $i$ prevod estetske informacije u nastavi" (rad izložen na konferenciji Kulture u prevodu) pokazuje da su gimnazijalci veoma zainteresovani za upoznavanjem sa originalnim tekstom i za integrisanu nastavu maternjeg i stranih jezika u oblasti književnosti. 
c) Obje tvrdnje - pod a) i pod b) - mogu biti djelimično i/ ili uslovno tačne i prihvatljive - tj. mogu se odnositi na neka književna djela, u zavisnosti od specifičnih odlika samog književnoumjetničkog ostvarenja (25\%)

d) Uloga čitaoca je aktivna - čitaocu je dozvoljeno da djelu dodaje čak i značenja koja autor nije imao u vidu $(41,66 \%)$

e) Vječno žive djela čija se recepcija (čitalački prijem) mijenja iz vijeka u vijek i kojem svaka generacija čitalaca daje sopstveni pečat $(8,3 \%)$

f) Vječno žive djela koja govore o univerzalnim pitanjima i u kojima čitalac može prepoznati samog sebe i svijet u svakom vremenu (58\%)

$U$ vezi sa tvrdnjom pod d), na primjer, ispitanici su pominjali različita djela, a i ovdje se javlja Balzakov naslov "Čiča Gorio“, kojem različiti čitaoci „dodaju“ različita značenja, naročito u tumačenju lika Ežena u posljednjem poglavlju i završnim rečenicama romana. Neki ispitanici ističu da je "dopisivanje“ značenja posebno moguće, dozvoljeno, pa i „obavezno“ u interpretaciji poezije.

Kao primjere za djela kojima se može ilustrovati stav $f$ ) učenici navode Bibliju, u kojoj postoji „svaka moguća tema“, Ep o Gilgamešu, Antigonu...

Ovdje treba istaći da tvrdnja pod f), za koju se odlučio najveći broj učenika srednjoškolskog uzrasta i gimnazijskog obrazovnog profila - korespondira sa nešto izraženijim interesovanjem za primjenu psihološkog metoda i kao spoljašnjeg i kao unutrašnjeg pristupa umjetničkom tekstu. Stav da vječno žive djela u kojima se čitalac svake epohe može prepoznati i u njima otkriti univerzalne istine o životu i svijetu - još jednom ukazuje na potrebu mladog čovjeka za upoznavanjem ljudske psihologije, a time i sebe samoga.

Sa druge strane, prisustvo raznovrsnih interesovanja koje su učenici nesumnjivo ispoljili - otvara brojne mogućnosti primjene tradicionalnih i modernih spoljašnjih i unutrašnjih pristupa tekstu, odnosno - realizacije pluralizma metoda u tumačenjima književnoumjetničkog teksta u samoj nastavi.

\section{Zaključak}

Književnost - umjetnost koja se materijalizuje kao jezička tvorevina, višeslojna i beskrajno bogata značenjima, oduvijek je predmet različi- 
tih tumačenja i naučnih analiza. Filološka istraživanja u klasičnom smislu dešifruju jezički kod, ali otkrivaju i brojne podatke koji su od značaja i drugim naukama. Tu se može naslutiti i polazište za dva osnovna metodološka pristupa tekstu - unutrašnji, koji se usredsređuje na sam tekst kao sistem i kao znak, i spoljašnji, koji uspostavlja veze sa kontekstom i podstiče interdisciplinarna istraživanja.

Programski sadržaji u nastavi književnosti i maternjeg jezika otvaraju mogućnost primjene različitih pristupa književnom tekstu, pri čemu se sam pluralizam pristupa percipira kao pluralizam mišljenja, ideja i stavova. To je pravo polazište za podsticanje intelektualnih aktivnosti, mašte i kreativnosti. U procesu vaspitanja i obrazovanja darovite djece ovo je od posebnog značaja. Sama različitost pristupa i višestruke mogućnosti primjene različitih metoda u tumačenju i analizi književnog djela - implicira otvorenost za razumijevanje drugačijih pogleda na određenu predmetnost, za pluralizam mišljenja uopšte, što je od naročitog značaja za razvijanje i njegovanje tolerantnog, otvorenog, demokratskog duha pojedinca, a time i društva.

Preliminarno istraživanje vršeno u Gimnaziji u Baru pokazuje da kod učenika zaista postoji interesovanje za različite metodološke pristupe umjetničkom tekstu, što svakako treba koristiti kako bi se i sama nastava učinila bogatijom i učenicima interesantnijom. Istraživanje ukazuje i na to da su interesovanja gimnazijalaca nešto više usmjerena ka spoljašnjim pristupima literarnom djelu, dok je strogo naučni, unutrašnji prstup umjetničkom tekstu po njihovom mišljenju manje privlačan („suvoparan“). Ovakvi stavovi uglavnom odgovaraju uzrastu ispitanika, njihovoj potrebi da se u interpretaciju teksta unese lični momenat, stav i doživljaj, a objektivnost i distanca strogo naučnog pristupa - isključuje, ili makar značajno sužava prostor za subjektivnost i aktivno učešće, „koautorstvo“ čitaoca.

Posebno treba naglasiti da spoljašnji pristupi (koji su uglavnom zasnovani na interdisciplinarnim proučavanjima i istraživanjima) istovremeno predstavljaju dobro polazište za integrisanu nastavu kojom se ostvaruju brojni vaspitni i obrazovni ciljevi. 


\section{Literatura:}

Bugarski, Ranko. Pismo. Beograd: „Čigoja“, 1996.

Đoređević Bosiljka, Maksić Slavica. Podsticanje talenata i kreativnosti mladih - izazov savremenom svetu. Zbornik Instituta za pedagoška istraživanja XXXVII/1. Beograd, jun 2005, 125-147

Đurišić-Bojanović Miroslava. Psihološke predispozicije nastavnika za podsticanje pluralističkog kognitivnog stila u nastavi. Zbornik Instituta za pedagoška istraživanja 40/1. Beograd, jun 2008, 54-69

Ingarden, 1931: R. Ingarden, Das litrarische Kunstwerk

Jakobson, Roman. Huit questions de poétiques. Paris: Édition du Seuil, 1977.

Jung K. G. Čovek i njegovi simboli. Beograd: „Narodna knjiga“, 1996.

Lipovetsky Gilles, Serroy Jean. L'esthétisation du monde. Paris: Gallimard, 2013. (reédition 2016)

Lotman J. M. Struktura umetničkog teksta. Beograd: „Nolit“, 1976.

Predmetni program Crnogorski jezik i književnost, I, II, III i IV razred opšte gimnazije. Podgorica: Ministarstvo prosvjete i sporta, Zavod za školstvo, 2011.

\section{Gordana Janjušević Leković}

\section{TRADITIONAL AND MODERN APPROACHES TO LITERARY TEXT IN MODERN TEACHING}

\section{Summary}

Classical philology has laid the foundation for all future, both traditional and modern, methodological approaches to literary studies. In the basic postulates of philological studies we find the starting point for any future analysis of a written text: linguistic - determining the linguistic code on which the text is based (which forms the basis for the twentieth century's internal approaches to text - linguistic-stylistic and structural methods), as well as the analysis of the context in the broader sense of the word - as a prerequisite for all later, both traditional and modern, exterior approaches to text, ranging from the praised but disputed positivist method, to the popular and largely accepted theory of reception. This paper will explore how much each of the modern methodological approaches is applicable and suitable in the teaching of language and literature, how much the today's high school students are familiar with the basics of modern methodological approaches to literature and also prepared to apply them to a certain extent, in accordance with their age (i.e. the level and profile of education), 
in a guided and/or independent analysis of literary texts. Specially, we should highlight the possibility of the advancement of consciousness and hearing for a sort of pluralism of ideas and opinions implicated by the pluralism of methodological - and methodical approaches to the artistic text. In such educational contents lies the key of a democratical education and future democratical capacity of a society. Individual's creative potential and the ability of divergent thinking gets recognised and it is developed within the literature and language teaching, and different literature approaches in this case are also adequate program content.

Key words: literature and language teaching, traditional approach, modern approach, internal approach to text, exterior approach to text, creative potential, pluralism 